\title{
Application of the Rapid Application Development Method to the BAZNAS Zakat Receipt Information System in Karawang
}

\author{
Muhamad Tabrani ${ }^{1}$, Hananda Priyandaru ${ }^{2}$, Suhardi $^{3}$ \\ ${ }^{1}$ Sistem Informasi, Universitas Bina Sarana Informatika, Indonesia \\ ${ }^{2}$ Sistem Informasi Akutansi, Universitas Bina Sarana Informatika, Indonesia
}

\begin{tabular}{l} 
Article Info \\
\hline Article history: \\
Received 29 April, 2021 \\
Revised 09 Juni, 2021 \\
Accepted 09 Juni, 2021 \\
\hline
\end{tabular}

\section{Keywords:}

Sistem Informasi RapidApplication Development Zakat

\begin{abstract}
Zakat is one of the pillars of Islam, it is obligatory for every Muslim to do it. In fact, there are still many Muslims who do not understand the types of zakat, zakat calculation, payment and processing of zakat, causing them forget to pay zakat. Moreover, in this modern era, people want do anything fast and practical. Even though if every Muslim and Muslimah is willing to pay zakat diligently, of course it can help improve the economy for the middle to lower class society. And of course zakat must be issued and processed according to the established rules. Information system development uses the Rapid Application Development System method, starting from the requitment planning, system design, and implementation phases, as result an objective information system. This website-based information system was built with HTML, CSS, Boostrap and PHP programming languages and for the database uses MySQL and for its web service uses Apache.
\end{abstract}

This is an open access article under the CC BY-SA license.

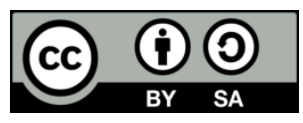

\section{Corresponding Author: \\ Muhamad Tabrani \\ Sistem Informasi \\ Universitas Bina Sarana Informatika \\ Email: Muhammad.mtb@bsi.ac.id \\ (C) The Author(s) 2021}

\section{Introduction}

The system is collection of people who work together with systematic and measured rules to form a unit to achieve goals. While information is data processing data to be more useful and meaningful for the recipient, and to reduce uncertainty in the decision-making process. An information system is an organized combination of people, hardware, software, communication networks and data resources that collects, transforms, and disseminates information within an organization [1]. An information system is a combination of information technology and the activities technology to support operation and management. The term information systems is often used to refer to the interactions between people, algorithmic processes, data and technology. In this sense, the term is used to refer not only to the organization's use of information and communication technologies (ICTs), but also to the ways of interaction in supporting business processes.

Linguistically, the word of "zakat" means to grow, to develop, to add or to increase. Zakat comes from the word "zaka" had meaning holy, good, blessing, growing and developing. It is called zakat because it contains the hope of obtaining blessings, cleansing the soul and cultivating it with various goodness. Information system applied in all fields to facilitate jobs. One of them is in the field of religion, for example the management of zakat at Badan Amil Zakat Nasional (BAZNAS). Zakat is charity tax for the poor or the needy. There are several 
types of zakat, there are: zakat mal, zakat fitrah, agricultural zakat, trade zakat, and other infaq. In zakat there are terms muzaki and mustahik. Muzaki is a person who is obliged to pay zakat, and mustahik is a person who has the right to receive zakat [2].

In terms of receiving zakat, BAZNAS Karawang still use conventional or manual methods. The method is to record and to receive muzaki data on sheets of paper, then make the report in notes book.due to many data were receipt, the staff felt difficult to process zakat every year. This conventional or manual methods has this have many disadvantages, such as loss data sheets, less accurate, longer process, and so on.

Based on the problems above, the researchers designed an information system for zakat acceptance at BAZNAS based on a client server to make the staff easier in managing zakat data by using the Rapid RAD method. Rapid Application Development (RAD) as an alternative from System Development Life Cycle is often used to overcome delay when using conventional methods. The advantages by using this method are faster, more accuracy, and lower costs than conventional methods [3]. Rapid Application Development (RAD) is a software development method with object-oriented approach toward system development. This method aims to shorten the time in planning, designing, and implementing a system than using traditional methods [4]. Thus the purpose of developing information system is to accelerate the process of zakat/infaq transaction services, assist the BAZNAS staffs in managing zakat/infaq. The result of the research can be utilized and used by agencies as reference for solving the problems.

\section{Research Methods}

\subsection{Software Development Method}

Rapid Application Development (RAD) is the method used in the design of the information system for the acceptance of Zakat Baznas in Karawang. Rapid Application Development (RAD) is a system development method with a prototyping approach designed to produce high-quality systems with relatively fast time and relatively low costs [4] Software development using the RAD rapid application development method has a Requirements Planning, User Design, Construction, and Implementation cycle [5].

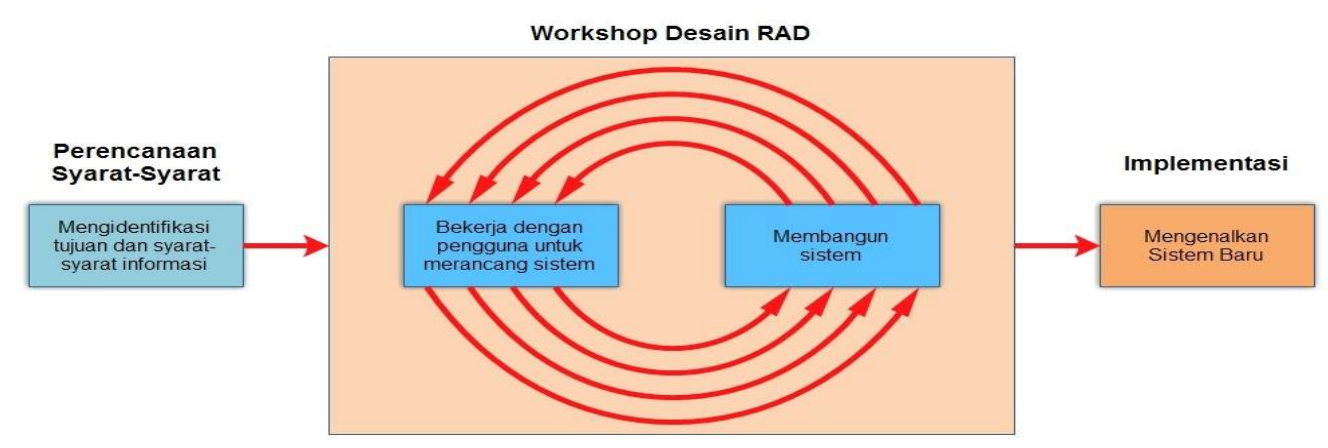

Figure 1. Rapid Aplication Development (RAD)

RAD has main elements as unique methodology including prototyping, iterative development, time boxing, the use of team members, management approach, and the use of tools in its implementing. Rapid Application Development (RAD) is a software development methodology focused on building applications in a very short time, simply comparing usability, features and execution speed. RAD method as an alternative of SDLC (System Development Life Cycle) method has been implemented to overcome the delay when using conventional methods. RAD method is suitable to produce software systems with urgent requirements and a short time in completing. RAD method is an object-oriented approach to produce a system with the main objective of shortening the processing time of application and process in order to immediately empower the software system appropriately and quickly [5].

Reasons for using Rapid Application Development (RAD) method[3]:

1. Using the RAD method can design acceptable to consumers and can develope easily.

2. RAD method Can provide limitations on a system so that it does not change.

3. Using RAD can save time, and if possible can save costs and produce quality products.

\subsection{Data Collection Techniques}

Data collection techniques are the most strategic step in research, because the main purpose of research is to obtain data. Data collection itself is a research phase when researchers apply scientific techniques to obtain 
systematic data for analysis purposes. Data collection techniques can be quantitative or qualitative. Meanwhile, quantitative research uses numerical data, and qualitative research uses contextual data [6]. Therefore, the data collection technique is the method of this research to collect important data related to the information system on Zakat Receipt at BAZNAS Karawang, the data collection technique consists of:

1. Observation

This method was conducted to observe zakat management activities [7]. Data collection techniques by conducting research and direct observation to BAZNAS Karawang. One of them is the observation of the needs was needed BAZNAS Karawang in the managing zakat and infaq.

2. Interview

Interview is one of the data collection techniques by face to face with the resourcer to answer the questions list [7] by interviewing directly related the problem.

3. Library research

Library research is a method of collecting data and studying theories and information from references, such as books, journals, e-journals, internet, lectures, articles and other readings related to the system to be built [8]. Library research method is used by the researchers to get good reference sources from books and articles on the internet to obtain data about good program design related to the research.

\section{Results and Discussion}

\subsection{System Requirements Analysis}

System requirements analysis was used the researcher in this research is designing website-based system provide information about zakat and zakat calculation services for user and for muzzaki is the system provides online zakat payment services [7]. In designing an information system for zakat receipts at Baznas Karawang, there are two users who can interact each other in the system, they are staff (admin) and Muzaki. The following are the information needs of each user:

\section{A. User Requirements}

In this system, there are 2 users staff or admin and Muzaki. Those users have interaction characteristics with different systems and have different information needs, such as the following:

A.1 Needs Scenarios for Muzaki

1. Provide personal data

2. Paying zakat/infaq

A2. Scenarios for staff or admin

1. Registering muzaki data

2. Inputting payment

3. Choosing the type of zakat/infaq

4. Making zakat / infaq report

\section{B. System Requirements}

1. staff or admin must log in first to be able to access Zakat Information System Website by entering username and password.

2. The system must be able to store data has been inputted by the staff or admin

3. staff or admin must log out after accessing Zakat Information System Website

\subsection{UML (Unified Modeling Language)}

Unified Modeling Language (UML) is a standard specification language used to document, specify and build software. UML is a methodology in developing object-oriented systems and is also a tool to support system development [9]. UML (Unified Modeling Language) as a description, planning, and sketching or arranging several separate elements into a unified whole [4].

\subsubsection{Use Case}

Use Case diagram is a pattern or picture to shows behavior or habits of the system.Use case diagram is a model for the behavior of the information system to be made. Use case describes an interaction between one or more actors with the information system to be created [10].

The components of the form Use Case Diagram are actors and use case. An actor represents a person or thing (such as a device, another system) interacts with the system. An actor may only provide information to the system (input), only receive information from the system (output) or both receive and provide information to the system (input-output). Actor is depicted with a stick man[11]. 


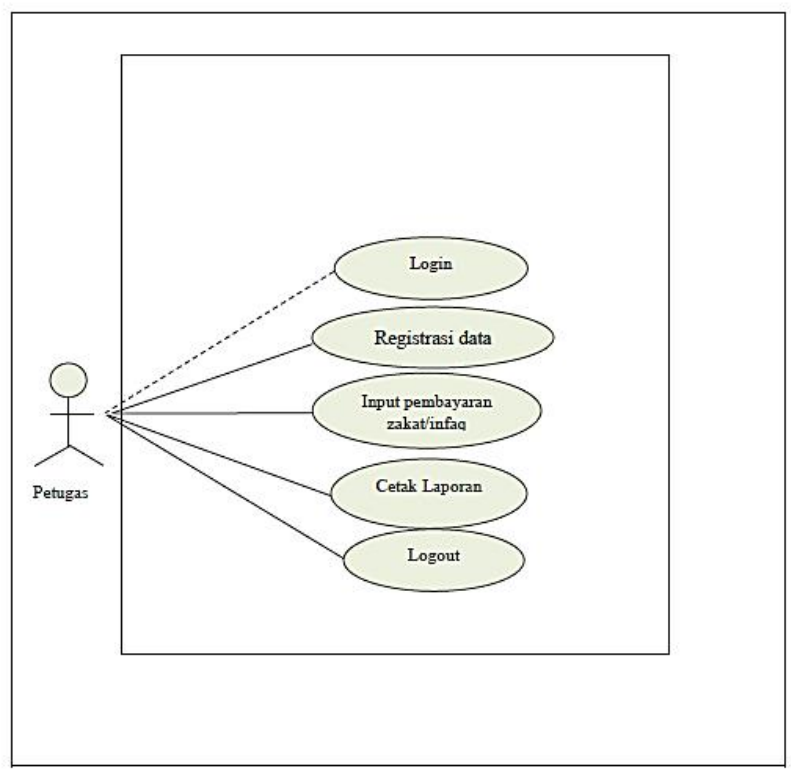

Figure 2. Use case Diagram

\subsubsection{Activity Diagram}

Activity Diagram describes the workflow (workflow) or activity of a system or business process. From the first to the end of this diagram, it shows the steps in the work process of the system [9].

Activity Diagram describes the workflow (workflow) or activities of a system or business process or menu in the software. It should be noted that the activity diagram depicts system activities not what actors do, but activities the system do [10].

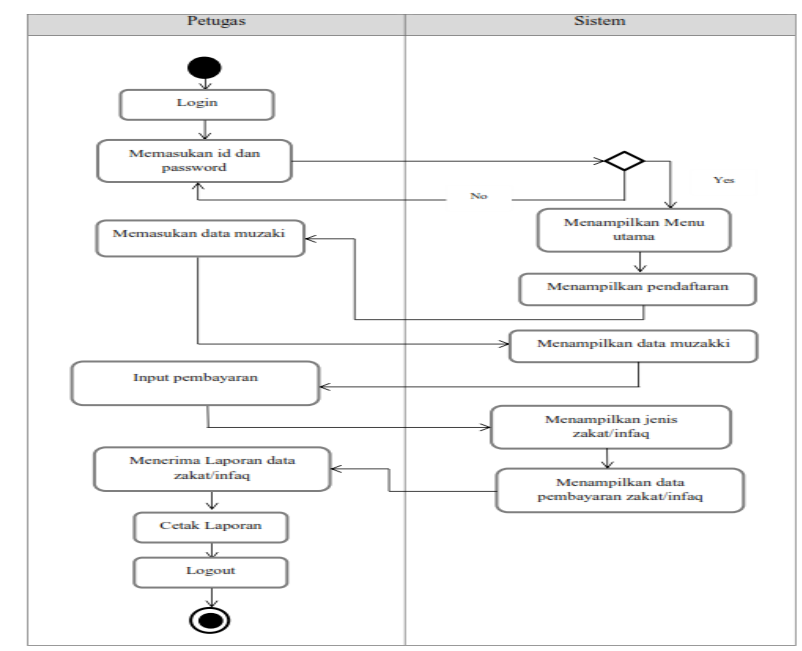

Figure 3. Activity Diagram

\subsubsection{Class Model/Class Diagram}

Class diagram describes the structure of the system in terms of defining the classes to build the system. Classes have attributes and methods or operations[10]. 


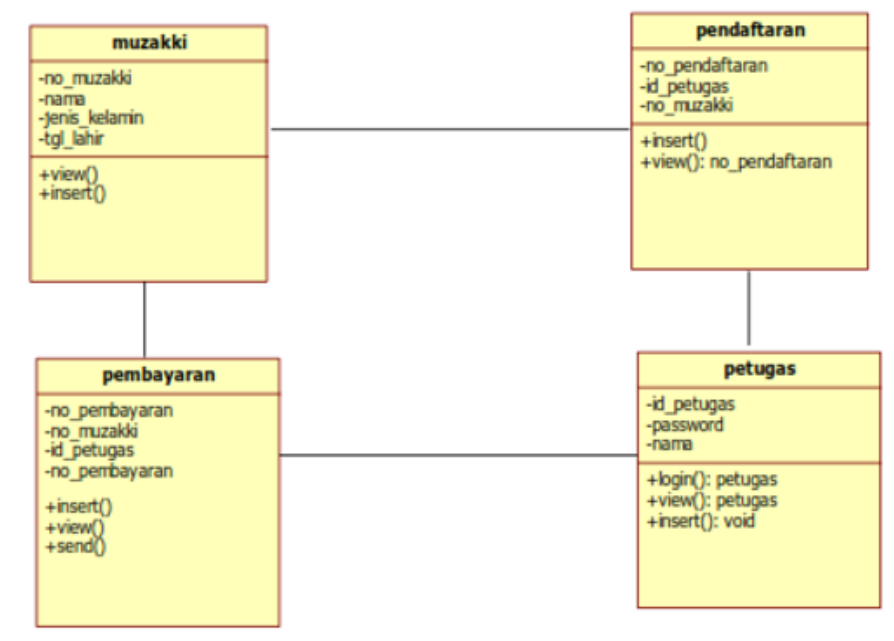

Figure 4. Class Diagram

\subsubsection{Sequence Diagrams}

Squence diagram describes the behavior of objects in use case by describing the life time of objects and messages sent and received between objects. To describe a sequence diagram, it is necessary to know the objects involved in use case and the methods the class that is initiated into the object.

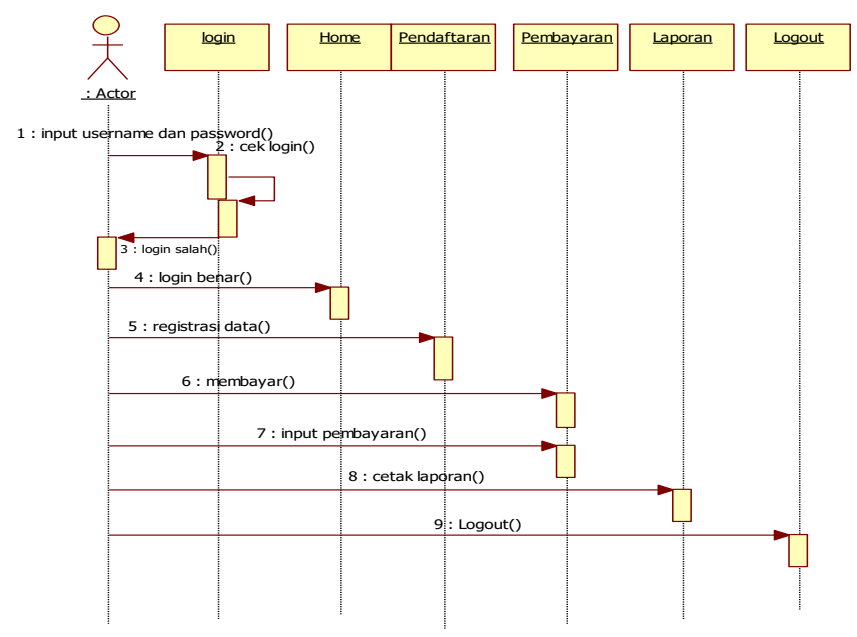

Figure 5. Squence Diagram

\subsection{Design Interface}

\subsubsection{Login Display/View}

Before entering the information system, staff or admin will be asked to log in first for security from the system, without login is not allowed to enter the system.

$$
\text { Login Baznas Karawang }
$$

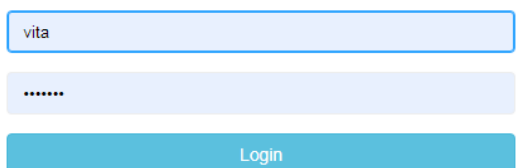

Figure 6. Design of Login Page 


\subsubsection{Main Page Display}

After successfully loggin, the staff or admin will enter the main page of BAZNAS Karawang zakat payment information system, on the main page there are several menus, registrations used to add muzaki data, transactions data of Muzaki, Zakat payments, Infaq payments and reports of income zakat and infaq per period.

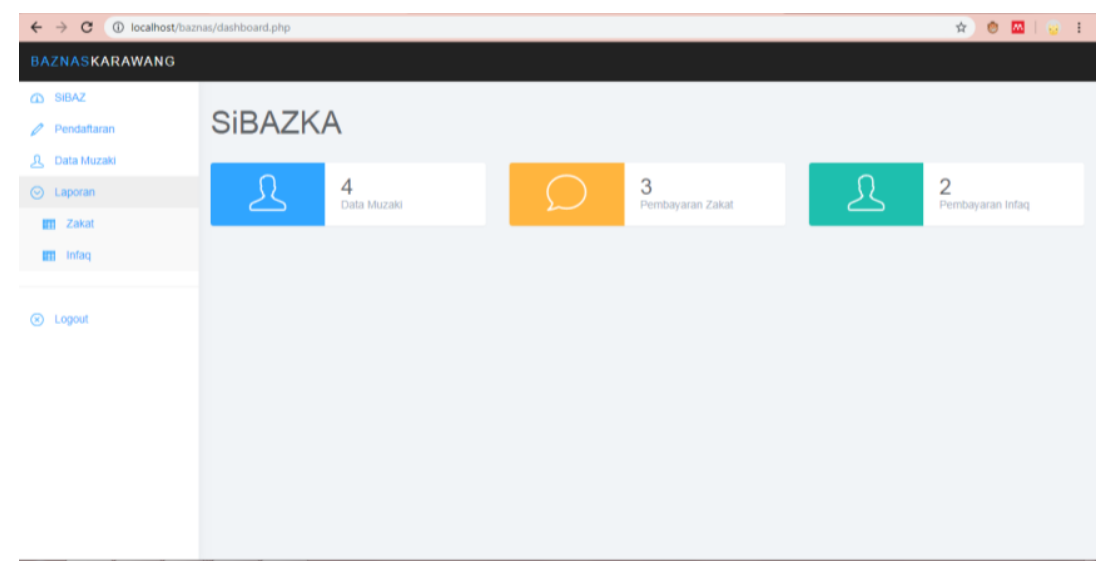

Figure 6. Design of Main Menu

\subsubsection{Display of zakat payments}

Here the staff or admin input data on zakat payments of Muzaki.

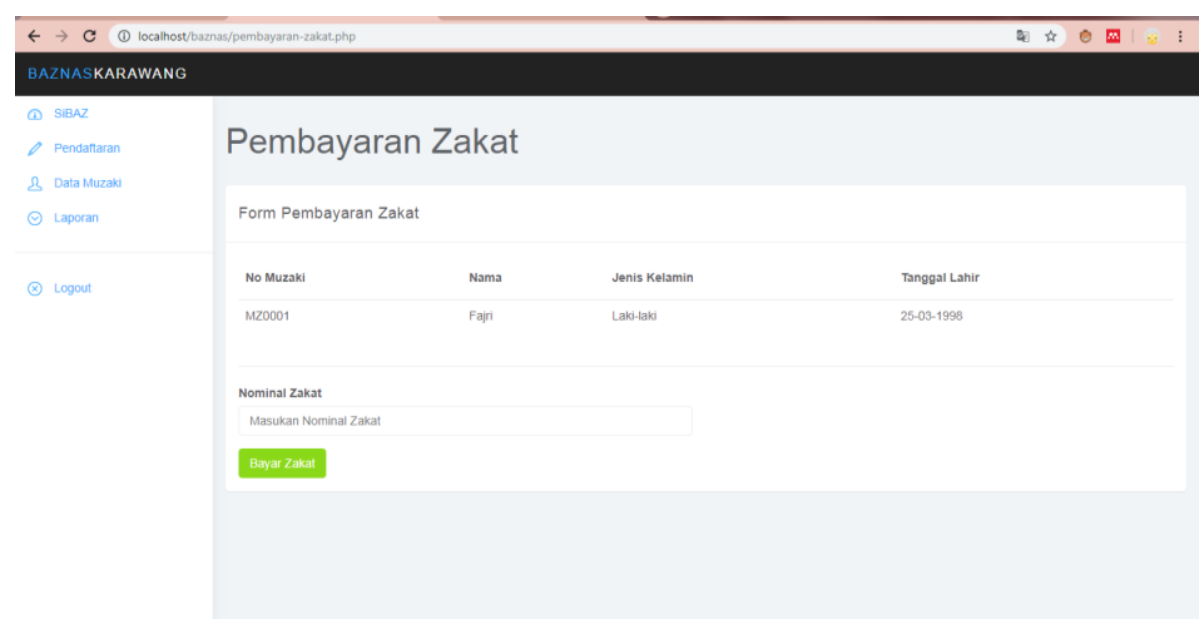

Figure 7. Design of Zakat Payments

\section{Conclusion}

From the discussion above, the system for receiving zakat / infaq can be concluded:

1. This system was built to facilitate the management of muzakki data and transaction data

2. This system was designed to make fast and accurate data processing

3. The job division between amil is more professional and effective because this system is a server and client server

4. Data has been stored can be used for a long time.

From the discussion of the zakat payment information system at BAZNAS Karawang can conclude the following as:

1. Zakat processing system has used computerized system now, but still manually before.

2. Using the website make easier for staff or admin to record muzakki data as result is no data redudation in terms of inputting muzaki data or payment transactions for muzakki data

3. Accelerate the process of making zakat receipt reports, thereby facilitating the distribution process of zakat is easier to receive.

4. In the future, it is necessary to create a mobile-based application so that muzaki can interact directly with the zakat information system and payment, it can cooperate with several banks or other online payment methods. 


\section{References}

[1] E. Y. Anggraeni, Pengantar Sistem Informasi. Penerbit Andi, 2017.

[2] S. S. Fikih Sunnah, "Panduan Zakat," Badan Amil Zakat Nasional. [Online]. Available: https://baznas.go.id/panduanzakat. [Accessed: 26-Sep-2020].

[3] F. T. Industri, J. T. Informatika, and U. K. Petra, "STUDI ANALISIS RAPID APLICATION DEVELOPMENT SEBAGAI PERANGKAT LUNAK Agustinus Noertjahyana," J. Inform., vol. 3, no. 2, pp. 74-79, 2002.

[4] M. Arya, R. Sikumbang, R. Habibi, and S. F. Pane, "Sistem Informasi Absensi Pegawai Menggunakan Metode RAD dan METODE LBS Pada Koordinat Absensi," J. MEDIA Inform. BUDIDARMA, vol. 4, no. 1, pp. 59-64, 2020.

[5] K. E. Kendall and J. E. Kendall, Systems analysis and design. Prentice Hall Press, 2010.

[6] Kelas Pintar, "Jenis-Jenis Teknik Pengumpulan Data Kualitatif," 2020. [Online]. Available: https://www.kelaspintar.id/blog/inspirasi/jenis-jenis-teknik-pengumpulan-data-kualitatif-3181/. [Accessed: 26Sep-2020].

[7] D. Supriadi and L. Fitriani, "Perancangan Sistem Informasi Zakat Berbasis Web," vol. 3, no. 1, pp. 1-8, 2018.

[8] S. A. Putri, L. A. Utami, and T. Dwiantoro, "Sistem Informasi Monitoring Perjanjian Kerja Sama Berbasis Web Pada PT Dayamitra Telekomunikasi Jakarta,” J. MEDIA Inform. BUDIDARMA, vol. 4, pp. 193-200, 2020.

[9] A. Hendini, "PEMODELAN UML SISTEM INFORMASI MONITORING PENJUALAN DAN STOK BARANG (STUDI KASUS: DISTRO ZHEZHA PONTIANAK)," J. Khatulistiwa Inform., vol. IV, no. 2, pp. 107-116, 2016.

[10] M. S. Rosa A S, Rekayasa Perangkat Lunak. Bandung: Informatika, 2016.

[11] W. Pradani, A. Jamal, W. Triansyah, Arie, and A. Utami, "Pengembangan Sistem Informasi Perpustakaan Menggunakan Teknologi Google Web Toolkit (GWT),”vol. 2, no. 2, pp. 96-103, 2016. 